\title{
DETERMINANT FACTORS OF MUSLIM TOURIST MOTIVATION AND ATTITUDE IN INDONESIA AND MALAYSIA
}

\author{
Mukhamad NAJIB \\ IPB University (Bogor Agricultural University), Department of Management, \\ Faculty of Economics and Management, Indonesia, e-mail: najib@apps.ipb.ac.id
}

\section{Retno Santi SUMARDI}

IPB University (Bogor Agricultural University), Department of Management, Faculty of Economics and Management, Indonesia, e-mail: shanty_0802@yahoo.com

\section{Siti NURLAELA}

IPB University (Bogor Agricultural University), Department of Management, Faculty of Economics and Management, Indonesia, e-mail: ella.elhamidy@gmail.com

\section{Farah FAHMA}

IPB University (Bogor Agricultural University), Department of Agroindustrial Technology, Faculty of Agrcultural Engineering and Technology, Indonesia, e-mail: farah_fahma@apps.ipb.ac.id

\author{
Citation: Najib, M., Sumardi, R.S., Nurlaela, S., \& Fahma, F. (2020). DETERMINANT FACTORS OF MUSLIM TOURIST MOTIVATION AND \\ ATTITUDE IN INDONESIA AND MALAYSIA. GeoJournal of Tourism and Geosites, 31(3), 936-943. https://doi.org/10.30892/gtg.31301-524
}

\begin{abstract}
Muslim tourists are one of the fastest growing segments in the global travel industry. The purpose of this study is to explore the determinant factors of Muslim tourist motivation and attitude in Indonesia and Malaysia. A total of 400 questionnaires were collected by purposive sampling. The findings showed that demographic differences do not affect the level of motivation of Muslim tourists. The process of finding information in the characteristics of tourist travel influences Muslim tourist motivation in traveling while most environment factor differs significantly on motivation level. Furthermore, the motivation has a positive influence to Indonesian and Malaysian consumer's attitude. Knowledge about the Muslim tourist motivation are the key to improve the services for the government and travel provider involved.
\end{abstract}

Key words: Muslim Tourist, Demographic, Travel Characteristic, Environtment factor

$* * * * *$

\section{INTRODUCTION}

The tourism industry is a whole series of businesses selling goods and services needed by tourists. Some aspects that characterize the tourist and influence their decision include: personality, self awareness, expectations, satisfaction, and loyalty to a particular destination (Ajzen and Fishbein, 2000). Another important element of the tourist decision-making process is the motivation. Knowing the tourist needs and motivations are the key to adapt to the requirements of demand, and also to improve the services offered by decision-makers and stakeholders involved in tourism to lead a successful business (Yeong et al., 2009).

Religion is one of the vital factors that affect some people's behavior and daily matters including leisure and tourism activities. For Muslims, religion provides guidance in all human activities (Hamed and Elmoghazy, 2018). World Muslim population with respect to the total world population has increased steadily from $15 \%$ in 1870 , to $17 \%$ in 1950 to $26 \%$ by 2020 , to $34 \%$ by 2070 (Kettani, 2010). According to Global Muslim Travel Index (GMTI) 2019, more than 230 million tourists are expected to embark on travel, locally and abroad by 2026. By that time, Muslim travelers are expected to inject $\$ 300$ billion into the global economy. Halal tourism has grown significantly in the last decade (Maghrifani, 2018). In this sense, the term "Halal" refers to practices allowed or approved in accordance with Islamic law (ElGohary, 2016). Muslim tourists represent one of the fastest growing segments in the global travel industry. Based on the GMTI 2019 results, the major highlight is Indonesia moving to be the joint top destination with Malaysia. Indonesia's ranking has been steadily increasing the last few years. Comparing to countries in South-East Asia, Indonesia has a rapid development in the Halal destination context (Kementerian, 2015). While Malaysia has successfully positioned itself in the top list among the countries that are considered as Muslim friendly destination (Kementrian and Kebudayaan, 2017).

There has been a growing consensus among tourism researchers that understanding tourist motivation and attitude is an important aspect in tourism (Nengovhela et al., 2017). Tourists' motivation is substantial to understand tourists' behavior (Maghrifani, 2018). Motivation refers to needs, goals and argues to influence preferences (Jiang et al., 2015). Segmentation based on tourists' motivation guides destination marketers in better product development, target promotion, and destination positioning (Boo and Jones, 2009).

Many studies have been done in the past to examine various dimensions of travel motivations that are the effect of religious dimensions (Chek, 2014). When it comes to Islamic tourism, there are many ambiguities surrounding the concepts (Hassan, 2015). This paper aims to identify the determinant factors of motivation and attitude of Muslim tourists. Moreover, with the global Muslim population growth, Halal tourism is undeniably becoming a huge niche market in the global tourism industry (Kim et al., 2015; Jeaheng et al., 2019). On the other hand, there was a drastic drop of Muslim travel to both USA and European Countries, in which this situation has provided an opportunity for Muslim countries to become popular destinations among Muslim travelers (Suid et al., 2017).

Among all destinations in Southeast Asia, Indonesia and Malaysia are the most similar in terms of their geographical location, people, history, language, culture, and natural resources (Tan et al., 2002). In view of the fierce competition and the many opportunities presented by the tourism industry, factors that affect international tourists' demand for Indonesia and Malaysia deserve immediate attenti on. Through this

\footnotetext{
${ }^{*}$ Corresponding author
} 
research, it is expected to be an input for the tourism industry players in formulating marketing strategies and also academics to enrich studies on motivation and attitudes in the tourism industry. The findings of the study also contribute to existing tourism literature by providing new empirical and region-specific evidence to the conceptual relationship between travelers' motivations and destination choices specifically related to Muslim travelers' motivation and halal-friendly destination.

\section{LITERATURE REVIEW}

\section{Tourist Motivation}

Tourists' motivation has long been an essential topic in the international tourism industry (Caber and Albayrak, 2016). The question of what motivates tourists to travel is a fundamental first step to generating an understanding of travel phenomenon (Agyeiwaah et al., 2019). Travel motivation is directly associated with reasons for tourists' behavior, and it is important to understand it (Lee and Gyumin, 2014). Travel motivation has always been considered as the essential part of the dynamic process of tourist behavior ( $\mathrm{Li}$ and Cai, 2016), which is of central interest to tourism marketers and managers in the design, planning, and promotion of tourism destinations. The core of marketing is to understand what motivates a consumer to buy a product. In the tourism industry, this refers to understanding what motivates tourists to travel and to buy a tourism product (Jiang et al., 2015). Definition or traveler's motivation, according to Jones (2011), is the reason why people travel, what the reasons for their traveling are, what they desire to fulfill from their traveling and why they chose one destination.

Tourism motivations are the reasons of the religious tourism development. Among the variety types of tourist's motivation such as holiday tourism, cultural tourism, social tourism, economic tourism and politics tourism, religious tourism is motivated by religious reason or faith (Laderlah et al., 2011). Muslim travelers' overseas traveling is an intended/directed behavior activated by their desire to fulfill their traveling needs and wants that comply with Islamic rules. Halal-friendly travel motivations refer to Muslim tourists' dynamic procedure of intrinsic psychological factors that direct their act and generate a state of pressure for conduction the behavior within the mselves (Han et al., 2019). In the halal tourism sector, convenient access to Muslim culture (e.g. accessibility to Muslim prayer place, familiarity with Islamic culture), halal-friendly tourism facilities (e.g. shopping facilities), quality of tourism infrastructure (e.g. airport, train, transport, road), technology, availability of halal-friendly service providers, halal-friendly travel environment, and availability of halal food service operations can be important travel motivation dimensions (Kim et al., 2015).

\section{Attitude}

Attitude is evaluation of people, objects and ideas. Attitude reflects a person's favorable or unfavorable evaluations, perceptions and feelings of executing a specific behavior. Consumer attitudes consist of 3 key elements: Affective, Behavioural and Cognitive. These three components are known as the ABC model of Attitudes. Affect relates to the emotional reaction of a consumer and the way they feel about an object. The behavioral component focuses upon the consumer's intention to respond in a certain manner toward an object and finally the cognitive element describes the consumer's beliefs about the object (Hawkins and Mothersbaugh, 2010). The interrelationship between the various factors of consumer behavior like motivation, belief and attitude is studied in reference to consumer market and industrial market (Najib and Kiminami, 2011). Many researchers have agreed that attitude is an evaluative judgment of products and services that helps in understanding consumers' specific attitudes toward those offerings (Fu et al., 2017; Kwun, 2011). Auf et al., (2018) found significant differences between the two national groups and posited that cultural orientation preconditions travelers' behaviors and attitudes toward a destination. Social, cultural, and economic factors have made the attitudes and behaviors quite different (Kim et al., 2015).

\section{Demographic and Tourist Motivation}

Many studies have explored the demographic factors in various research fields, such as attitude (Lee and Hwang, 2011), motivation (Zhang and Peng, 2014), food preference (Mak et al., 2012), online channel selection (Qi et al., 2013), and destination image (Beerli and Martín, 2004). Theoretically, Demographic attributes refer to several indicators, such as age, gender, marital status, educational level, occupation, and income level (Mak et al., 2012). These indicators played a crucial role in explaining the difference in lifestyles and travel motivations (Kim and Chulwoo, 2020). Demographic change can affect different aspects of tourism. It impacts directly on tourist demand, the tourism labor market, and has an indirect effect on jobs within the tourism industry and tourism services (Grimm et al., 2009). One of the research on demographics related to tourism is conducted by Jensen and Hjalager (2013) which mentions that younger travelers are the firstmovers in taking advantage of online media. The use of social media for information sharing is consistently related to socio-demographic factors as well as to travel motivations. Furthermore, age has a positive correlation with the sense of relaxation and nature exploration, while education level is positively related to motivation regarding social influence (Ma et al., 2018). Some research indicates that different demographic characteristics and motivational factors have relationship with each other for tourists. Yu (2012) found that older individuals take trips mainly to meet new people and culturally interact with local residents, arguing that this function of tourism particularly appeals to older individuals, who generally lack sufficient opportunities to interact with others. Many older individuals selected human relationships as the most important motivation to travel, while this motivation has been infrequently cited in previous studies on younger generations, whose motivations were more varied and included education, excitement, self-actualization, and risk-seeking (Ryu et al., 2015). There were significant differences based on nationality regarding travel motivations of tourists (Jonsson and Dwayne, 2008). Kim and Seokho (2000) concluded that the difference in travel motivation was attributable to the gap between cultures. Japanese tourists exhibited more collectivistic characteristics in travel motivation while American tourists showed more individualistic characteristics. Kozak (2002) took a direct approach to examine the differences in tourist motivations between nationalities and destinations. The study found that the factor structure of a measure of travel motivations comprised four dimensions of motives: cultural motives, pleasure-seeking/fantasy-based motives, relaxationbased motives, and physical motives. The results showed motivational differences between nationalities. Travel providers should ascertain customer motivations based on an interrogation of demographic data in order to provide satisfying travel experiences.

\section{Traveler Characteristic and Motivation}

Traveler characteristics include six aspects: travel companion, travel frequency, main travel purpose, recommendation, the strongest influencer, and price acceptance (Lou, 2014). Traveler characteristics affect the information search. Information search comes from both internal and external sources. When a person decides to travel, he/she gathers information to make informed travel decisions. Information search behaviors have also been seen to influence outcomes such as length of stay, spending, and number of attractions visited (Fodness and Murray, 1999). Information search prior traveling is done through internet, guidebooks, family and friends (Perret, 2007).

Recommendation from friends was ranked the first most used information source (Lou, 2014). Lou (2014) also mentioned that discovering the travel characteristics that influence motivations can be applied to tourism market segmentation studies. 
Perrett (2007) indicated that tourist who conform to certain characteristics may be more likely to have some motivation than other. Tourists' travel characteristic features reflect that it is helpful to use a motivational approach to identify their expectations and predict their future behavior. The motivation of potential travelers is a multidimensional construct that demonstrates distinctive characteristics. By analyzing tourist's characteristics according to segments, travel provider can identify their travel motivation and correctly select target markets to cater to their particular needs and wants (Otoo et al., 2020). Tourism market segmentation is undertaken by grouping characteristics to predict potential behavior and to direct specific marketing strategies for each segment (Alén et al., 2016).

\section{Environmental Factors and Motivation}

Environmental factor is a factor outside the individual consumer that influences travel motivation. According to Engel et al., (1995) environtmental factors can be categorized as physical environment and social environment. Physical environmental factors are related to place, attraction and so on. For the Muslim traveler, halal environment is important factor to decide a destination. The halal environment according to (Abror et al., 2019) relates to the availability of halal products and facilities, such as halal foods and kitchen. Moreover, Battour et al., (2017) explain that there are some halal or Islamic tourism attributes, they are worship facilities, halal, general Islamic morality and alcohol drinks and gambling free. Besides physical environment, social environment also influences motivation of Muslim traveler. Social environmental factors are in the forms of culture, social class, reference groups, families and situations influencing tourist behavior. According to Jang and Cai (2002) recognition and admiration from neighbors, friends, and workers are part of social environment that is important as a motivational factor for traveler. Moreover, cultural factors, social classes, reference groups, and families have influence on motivation of traveler to visit centain destination (Baker and Ritsuko, 2008).

\section{Travel Motivation and Consumers' Attitude}

Motivation can be described as an "energising force" (Hawkins and Mothersbaugh, 2010) that activates certain behaviours that in turn provides purpose and direction to these behaviours. Psychological factors such as motivation and consumer attitude are all influential factors that affect consumer decision making (Vainikka, 2015; Auf et al., 2018). Factors such as information sources, travel motivations, and sociodemographic characteristics also have an impact on destination image formation (Chek, 2014). Strong motivations are also exhibited among people with a strong commitment to travel (Agyeiwaah et al., 2019). Eventually, revisit intention is affected by tourist motivation (Kim et al., 2015). Although theoretical connectedness exists for tourists' motivation and consumers' attitude (Chu, 2011; Taylor et al., 2011), no study has empirically identified the relationship between demoghrapic, travel characteristic, and environment factors on motivation and consumers' attitude among Muslim tourist. Targeting Muslim tourist market may not be the same as targeting the mundane tourism segment (Suradin, 2018). The model we posited in here as a determinant factor that motivated Muslim to choice of destination.

\section{MATERIALS AND METHODS}

This research was conducted in Indonesia and Malaysia. Lombok was chosen to represent halal tourism of Indonesia and Kuala Lumpur were chosen to represent Malaysian halal tourism. According to Ministery of tourism and culture of Malaysia (2017) Kuala Lumpur as a region in Malaysia which received an award from the Muslim Travel Shopping Index (MTSI) in 2015 as the second best Muslim shopping. Meanwhile Lombok is a pioneer of Sharia Tourism Destination in Indonesia, with 1000 mosques available and local regulations on halal tourism (Khan and Michelle, 2017). Time of this research is held on May-September 2018.

Survey was used to generate information about the motivation factors that influence attitude. It was conducted by distributing surveys to Muslim respondents. Respondents were chosen based on the purposive sampling method. The criteria of respondents in this study are Malaysian Muslim traveler who visited in Lombok and Indonesian Muslim traveler who visited in Kuala Lumpur. Survey was conducted in Lombok and Kuala Lumpur. The questionnaire consists of several questions that will be scored using likert scale (1-5) and with closed question. The total number of samples used in this study were 400 respondents consisting of 200 respondents from Malaysia and 200 respondents from Indonesia. Following the rule of thumb for determining sample sizes by VanVoorhis and Morgan (2007), 200 participants are enough to maintain adequate power when using independent t-test statistics and one way ANOVA. In reviewing the factors that influence consumer decisions, the purposive sampling technique has been applied in this research. Purposive sampling is a technique of determining the sample with certain considerations. Data collection method used is with self administered questionnaires, for example respondents are asked to fill in their own questionnaire given. The scope of this study will limit the factors that effect the motivation such as demographic factors, tourist characteristics and environtment factors, and the effect motivation factors to consumer attitude.

The variables observed of this research are as follow:

a. Demographic factors (X1). According to Khalabikhina and Shishalov (2016) segmentation and analysis of the relationship between socio-demographic variables and travel motivation could be based on gender, age, social relationship with family or friends, education, income and region.

b. Traveler characteristics (X2). The variables of traveler characteristics such as family status, influencer, information search and factors considering to choose destination (e.g. price, safety, easy to access) influence Muslim traveler motivation. Perrett (2007) indicated that traveler who conform to certain characteristics may be more likely to have some motivation than other.

c. Environmental factors (X3) is a factor outside the individual consumer that influences decisions. In this study, environmental factors refer to social environmental factors. According to Baker and Ritsuko (2008) Muslim norm, social class, family, religion condition, and friends are environmental factors that influces Motivation of Muslim traveler.

d. Motivation (Y) is the reason why people travel, what the reasons for their traveling are, what they desire to fulfill from their traveling and why they chose one destination to travel (Jones, 2011). Motivation has a dominant influence on consumer decision on traveling. According to Muhammad (2017) motivation consists of self fulfillment needs, self esteem needs, relationship needs, safety, and physiological needs.

e. Consumer attitudes $(Z)$ is reflects a person's favorable or unfavorable evaluations, perceptions and feelings of executing a specific behavior. Consumer attitudes consist of three key elements: Affective, Behavioural and Cognitive.

Based on the literature review and the objective of this study, hypotheses developed as follow:

H1: Demographic factors influence motivation of Muslim tourist

H2: Traveler characteristic influences motivation of Muslim tourist

H3: Environmental factors influence motivation of Muslim tourist

H4: Motivation of Muslim tourist affects consumers' attitude 
This study is to explain demographic differences, differences in travel characteristics and environmental differences on motivation between Indonesian and Malaysian consumers, and also to analyze the effect of motivation on consumer attitudes in both Indonesia and Malaysia. To get results, these variables will be analyzed by independent t-test analysis and ANOVA using SPSS.

\section{RESULTS DISCUSSIONS}

\section{Effect of demographic on motivation}

Demography in economics is a lifestyle. Lifestyle is the lifestyle of a person in the world revealed in the activity, interests and opinions. Personality is a unique characteristic of the behavior of someone different from each other (Jaelani, 2017). Personality between women and men is also different when deciding to take a vacation. Kattiyapornpong and Miller (2008) suggested that demographic variables may act as qualifying variables or constraining variables rather than determining variables of travel behavior. To evaluate the relation ship between motivation and demographic variables, the total mean score of items related to the motivation dimension was computed. This variable was subjected to a normal test, and the results indicated that the mean score of motivation is distributed normally. Afterwards, this mean score was compared across different levels of socio-demographic variables through parametric tests, including independent $t$-test and one way ANOVA. The effect of demographic on motivation Indonesian and Malaysian consumer can be seen on Table 1 and Table 2.

Table 1. The effect of demographic on motivation Indonesian consumer

\begin{tabular}{|l|l|c|c|c|c|c|}
\hline Variable & Level & $\mathrm{N}$ & Mean & SD & t/F & p-value \\
\hline Age & $18-40$ & 178 & 19.60 & 2.62 & & \\
& $41-60$ & 21 & 19.5 & 2.8 & 0.150 & 0.861 \\
& $>60$ & 1 & 21 & 2.63 & & \\
\hline Gender & Man & 67 & 19.6 & 2.7 & 0.007 & 0.934 \\
& Women & 133 & 19.59 & 2.59 & & \\
& Lower & 14 & 19.5 & 2.74 & & 0.910 \\
& Lower middle & 32 & 19.44 & 2.49 & \multirow{2}{*}{0.180} & \\
& Upper middle & 76 & 19.78 & 2.74 & & \\
& Upper & 78 & 19.53 & 2.60 & & \\
& Basic & 6 & 18.16 & 2.48 & & \multirow{2}{*}{0.281} \\
& Middle & 48 & 19.37 & 2.22 & & \\
& High & 146 & 19.73 & 2.75 & & \multirow{2}{*}{0.275} \\
& Student & 41 & 19.39 & 2.49 & & \\
& Private employee & 74 & 20.0 & 2.65 & & \\
& Public servant & 27 & 18.78 & 2.61 & & \\
& Entrepreneur & 48 & 19.75 & 2.59 & & \\
& Others & 10 & 19.1 & 3.1 & & \\
\end{tabular}

Based on Table 1, the age of 18-40 was the most dominating in this study both Indonesian consumer and Malaysian consumer, age simultaneously affects income, thus income and age will also influence decisions. According to Pramika (2017), income increases with age, where the age of 18-40 years is that of having high income. Based on p-value ( $>0.05)$, motivation of Indonesian and Malaysian consumer are not statistically different between age groups. Woman has the highest number in this study both Indonesian and Malaysian consumer, research conducted by Cosmin (2012) showed that women tended to be pioneers in decision making. A wife have an important role in the decision of destination for family vacation (Arizon et al., 2010). Moreover a wife also have an important role in finding accommodation information, shopping and choosing a travel agent (Decrop 2005). However in this study, motivation of Indonesian consumer is not statistically different between man and women ( $\mathrm{p}$-value $>0.05$ ).

Table 2. The effect of demographic on motivation Malaysian consumer

\begin{tabular}{|c|c|c|c|c|c|c|}
\hline Variable & Level & $\mathrm{N}$ & Mean & SD & $\mathrm{t} / \mathrm{F}$ & p-value \\
\hline Age & $\begin{array}{l}18-40 \\
41-60 \\
>60\end{array}$ & $\begin{array}{c}193 \\
7 \\
0\end{array}$ & $\begin{array}{c}20.06 \\
20.86 \\
-\end{array}$ & $\begin{array}{c}2.3 \\
3.29 \\
- \\
\end{array}$ & 0.765 & 0.383 \\
\hline Gender & $\begin{array}{l}\text { Man } \\
\text { Women }\end{array}$ & $\begin{array}{c}62 \\
138\end{array}$ & $\begin{array}{l}20.39 \\
19.96\end{array}$ & $\begin{array}{l}2.19 \\
2.40\end{array}$ & 1.396 & 0.239 \\
\hline Income & $\begin{array}{l}\text { Lower } \\
\text { Lower middle } \\
\text { Upper middle } \\
\text { Upper }\end{array}$ & $\begin{array}{l}36 \\
34 \\
73 \\
57 \\
\end{array}$ & $\begin{array}{l}20.67 \\
20.36 \\
20.36 \\
19.23 \\
\end{array}$ & $\begin{array}{l}2.54 \\
2.02 \\
1.78 \\
2.82 \\
\end{array}$ & 3.947 & 0.009 \\
\hline Education & $\begin{array}{l}\text { Basic } \\
\text { Middle } \\
\text { High }\end{array}$ & $\begin{array}{c}- \\
36 \\
164 \\
\end{array}$ & $\begin{array}{c}- \\
19.89 \\
20.14\end{array}$ & $\begin{array}{c}- \\
2.81 \\
2.24\end{array}$ & 0.338 & 0.562 \\
\hline Occupation & $\begin{array}{l}\text { Student } \\
\text { Private employee } \\
\text { Public servant } \\
\text { Entrepreneur } \\
\text { Others }\end{array}$ & $\begin{array}{c}50 \\
90 \\
8 \\
48 \\
4 \\
\end{array}$ & $\begin{array}{c}20.54 \\
19.9 \\
20.5 \\
19.64 \\
22.5 \\
\end{array}$ & $\begin{array}{c}2.17 \\
2.29 \\
2.73 \\
2.41 \\
3.0 \\
\end{array}$ & 2.141 & 0.077 \\
\hline
\end{tabular}

The most dominant monthly income for Indonesian consumer was in upper income and for Malaysian consumer is upper middle, meaning that the income of visitors to halal tourism in Indonesia and Malaysia in this study was dominated by tourists with high income. This result can also mean that with a high income they can save some money to care more about their lifestyle including doing halal tourism.

Based on p-value $(>0.05)$, motivation of Indonesian consumer is not statistically different between income groups but for Malaysian consumer p-value $(<0.05)$, so those who have lower income $(\mathrm{M}=20.67, \mathrm{SD}=2.54)$ have the highest motivation to come to Indonesian halal tourism, compared with the lower middle, upper middle and upper income. Lower income has the highest motivation is because the curiosity has the biggest part to try and discover Indonesia, and because convenience and affordable prices make even lower income groups can buy flight tickets, stay costs, food and souvenir. Moreover local transport tickets is easily to get from their home country. Respondents with 
higher educational backgrounds occupied the highest number in Indonesia and Malaysia. The level of education can influence the person in making decisions during the trip. According to Jensen and Hjalager (2013), education is very closely related to work and income, for example the higher the educational background, the better the job to be obtained, thus affecting one's income. It is well known that the higher the income, the greater the chance for someone to maintain one's lifestyle, including halal tours to certain destinations. However, based on pvalue (>0.05), motivation of Indonesian and Malaysian consumer is not statistically different between the education groups. Based on the type of works of the respondents, the profession as an employee in the private sector was the most dominant both in Indonesian and Malaysian consumer. The work done by consumers will affect their lifestyle. Nevertheless, in this study, based on p-value (>0.05), motivation of Indonesian and Malaysian consumer is not statistically different between profession groups.

\section{Effect of traveler characteristics on consumer motivation}

Test ANOVA was also used to address the second research objective. Traveler characteristics in this study are status, influencer, information search and considering to choose destination. The result are presented in Table 3.

Table 3. Traveler characteristics on Indonesian and Malaysian consumer motivation

\begin{tabular}{|c|c|c|c|c|c|c|}
\hline Variable & Level & $\mathrm{N}$ & Mean & SD & $\mathrm{t} / \mathrm{F}$ & p-value \\
\hline \multicolumn{7}{|c|}{ Indonesian Consumer } \\
\hline Status & $\begin{array}{l}\text { Merried } \\
\text { Single }\end{array}$ & $\begin{array}{c}80 \\
120\end{array}$ & $\begin{array}{l}19.68 \\
19.56\end{array}$ & $\begin{array}{l}2.58 \\
2.67\end{array}$ & 0.094 & 0.759 \\
\hline Influencer & $\begin{array}{l}\text { Friends } \\
\text { Family } \\
\text { They self } \\
\text { Others }\end{array}$ & $\begin{array}{c}52 \\
57 \\
89 \\
2\end{array}$ & $\begin{array}{c}19.83 \\
19.72 \\
19.34 \\
22.5\end{array}$ & $\begin{array}{l}2.23 \\
2.42 \\
2.34 \\
2.25\end{array}$ & 1.281 & 0.282 \\
\hline Information search & $\begin{array}{l}\text { Print media } \\
\text { Electronic media } \\
\text { Verbal } \\
\text { Agent }\end{array}$ & $\begin{array}{c}11 \\
147 \\
25 \\
17 \\
\end{array}$ & $\begin{array}{l}21.45 \\
19.53 \\
19.92 \\
18.59 \\
\end{array}$ & $\begin{array}{l}2.34 \\
2.53 \\
1.92 \\
1.59 \\
\end{array}$ & 2.901 & 0.036 \\
\hline $\begin{array}{l}\text { Considering to choose } \\
\text { destination }\end{array}$ & $\begin{array}{l}\text { Price } \\
\text { Easy to communicate } \\
\text { Safety and security } \\
\text { Good name of places }\end{array}$ & $\begin{array}{l}91 \\
23 \\
47 \\
39\end{array}$ & $\begin{array}{l}2.57 \\
3.08 \\
2.66 \\
2.35\end{array}$ & $\begin{array}{l}2.57 \\
3.08 \\
2.66 \\
2.35\end{array}$ & 1.692 & 0.170 \\
\hline \multicolumn{7}{|c|}{ Malaysian Consumer } \\
\hline Status & $\begin{array}{l}\text { Married } \\
\text { Single }\end{array}$ & $\begin{array}{c}64 \\
136\end{array}$ & $\begin{array}{l}19.75 \\
20.26\end{array}$ & $\begin{array}{l}2.57 \\
2.22\end{array}$ & 2.046 & 0.154 \\
\hline Influencer & $\begin{array}{l}\text { Friends } \\
\text { Family } \\
\text { They self } \\
\text { Others }\end{array}$ & $\begin{array}{c}71 \\
67 \\
54 \\
8\end{array}$ & $\begin{array}{c}20.59 \\
19.79 \\
19.8 \\
20.0\end{array}$ & $\begin{array}{l}1.88 \\
2.64 \\
2.59 \\
0.53\end{array}$ & 1.681 & 0.172 \\
\hline Information search & $\begin{array}{l}\text { Print media } \\
\text { Electronic media } \\
\text { Verbal } \\
\text { Agent }\end{array}$ & $\begin{array}{c}2 \\
126 \\
31 \\
41\end{array}$ & $\begin{array}{l}20.0 \\
20.3 \\
20.2 \\
19.4\end{array}$ & $\begin{array}{l}0.00 \\
2.01 \\
2.89 \\
2.80\end{array}$ & 1.481 & 0.221 \\
\hline $\begin{array}{l}\text { Considering to choose } \\
\text { destination }\end{array}$ & $\begin{array}{l}\text { Price } \\
\text { Easy to communicate } \\
\text { Safety and security } \\
\text { Good name of places }\end{array}$ & $\begin{array}{l}101 \\
25 \\
47 \\
27\end{array}$ & $\begin{array}{c}19.97 \\
19.9 \\
20.51 \\
20.0\end{array}$ & $\begin{array}{l}2.42 \\
2.25 \\
2.27 \\
2.30\end{array}$ & 0.645 & 0.587 \\
\hline
\end{tabular}

The results presented in Table 3, show that the level of Indonesian consumers motivation differs significantly among different levels of information search with the ( $\mathrm{t}$-value $=2.901 ; \mathrm{p}$-values $<0.05)$, where by using print media, Indonesian consumers will be more motivated to visit Malaysia with $(\mathrm{M}=21.45 ; \mathrm{SD}=2.34)$. While for Malaysian consumers motivation is not significantly different $(\mathrm{p}$-value $>0.05)$.

\section{Effects of Environmental factors on consumer motivation}

Table 4 showed that the motivation of Indonesian traveler is significantly different in terms of levels of Muslim norm, social class, family, religion condition and friends. Environmental factors are factors that shape the behavior of tourism consumers such as culture, social class, reference groups and families influencing tourist behavior. Cultural, social class, reference groups and family factors partially influence the visiting decision-making process of tourists (Baker and Ritsuko, 2008). The community environmental factors and the convenience of tourist attractions are some of the elements supporting tourism. In this study, the motivation of Malaysian traveler differs significantly among different levels of Muslim norm, social class, family, religion condition except friends. Friends in this context means friends as a reference group that influencing consumer to get the motivation to go or not to go to chosen destination.

Table 4. Environtmental factor on Indonesian and Malaysian consumer motivation

\begin{tabular}{|l|c|c|}
\hline \multicolumn{1}{|c|}{ Variable } & $\mathrm{t} / \mathrm{F}$ & P-value \\
\hline \multicolumn{2}{|c|}{ Indonesian consumer } & 0.000 \\
\hline Muslim norm & 12.69 & 0.000 \\
\hline Social class & 10.633 & 0.000 \\
\hline Family & 9.524 & 0.000 \\
\hline Religion condition & 28.46 & 0.000 \\
\hline Friends & 6.720 & 0.000 \\
\hline & Malaysian consumer & 0.000 \\
\hline Muslim norm & 28.284 & 0.004 \\
\hline Social class & 32.522 & 0.000 \\
\hline Family & 3.948 & 0.096 \\
\hline Religion condition & 24.354 & \\
\hline Friends & 1.999 & \\
\hline
\end{tabular}




\section{Effect of motivation on attitude of consumer}

Motivation is a key factor in tourist behavior and is fundamental to the development of tourists (Zhang and Peng, 2014). Meanwhile Kellerman (2014) mentioned that hierarchy of need from Maslow is the key theory of travel motivation, where everyone has different motivations and different needs when visiting tourist attractions. Attitude is one of the most important concepts used by marketing to understand consumers and important factors that will influence consumer decisions. Test the effect of motivation to attitude analyzed by SPSS ANOVA, can be seen in Table 5 .

Table 5. Effect of Motivation Indonesian and Malaysian consumer to attitude

\begin{tabular}{|c|c|c|c|}
\hline Consumer & $\mathrm{t} / \mathrm{F}$ & $\mathrm{p}$-value & $\mathrm{R}^{2}$ \\
\hline Indonesian consumer & 47.339 & 0.000 & 0.439 \\
\hline Malaysian consumer & 118.843 & 0.000 & 0.612 \\
\hline
\end{tabular}

Based on Table 5, the result of effect motivation on attitude have a p-value $<0.05$, it can be concluded that there is a positive influence between the motivation of Indonesian and Malaysian consumers on attitude in halal trips both to Indonesia or to Malaysia, it means that the increasing of motivation to come to halal tourism both in Indonesia or Malaysia and make the tourist come back to visit. This study is also in line with the research of Mahmoud (2014) which states that motivation has a positive relationship and have a direct and positive effect on attitude. Moreover, $\mathrm{R}^{2}$ value are 0.439 for Indonesian consumer and 0.612 for Malaysian consumer meaning that variable of motivation has $43.9 \%$ and $61.2 \%$ preditictive power to explain Indonesian and Malaysian travelers' attitude.

\section{THEORETICAL AND MANAGERIAL IMPLICATIONS}

This study is vital for several reasons. First, it extends Chek's (2014) studies of travel motivation dimension from Muslim tourist perspective. Second, it extends discussion on the attitude of Muslim tourist who are more and more in number. Third, the results derived from this study could give the Indonesia and Malaysia government an insight of what motivates Muslim tourists to visit a tourist destination and perhaps encourage the government to set strategic policies to better host Muslim tourist. Furthermore, when dealing with Muslim tourist, implementing some of the approaches of this study will make a comprehensive resource for travel agencies. By understanding what factors motivate Muslim tourists to travel and believe that motivation influences tourist attitudes, travel service providers can cre ate more attractive promotional packages with specifications that are on target including promotion in online media (Nurlaela et al., 2019). For example, making travel package advertisements by highlighting the ease of getting halal food or access to worship for Muslims. These findings would help tour operator to provide better facility and services for Muslim tourist and cater them more cautiously.

\section{CONCLUSION}

This research was one of few studies to develop a conceptual framework by comprising Muslim tourists' motivations as major variables and considering its effect on Muslim tourists' attitudes. This study examines demographics, travel characteristics, and environment as determinants of travel motivation. In addition, this study complements previous research by Han et al., (2019), which tested accommodation, food, facilities, encounter services, and other tourists as determinants of tourist motivation. Overall, the findings of this study help us to have better understanding about the determinant factors of Muslim tourists' motivation. Moreover, our results help us better comprehend the role of travel motivations on their attitude to consider tourist destinations.

This study indicated that the Muslim tourists surveyed had demographic differences groups on age, gender, education, and occupation that was concluded not statistically different on motivation of Indonesian and Malaysian consumer. However, also need to be said that for Malaysian consumer, tourist who has lower income, has the highest motivation to come to Indonesian halal tourism, compared with the lower middle, upper middle, and upper income. Choosing promotional activities specifically targeting lower income consumers can be a smart decision for the government and travel providers in Indonesia to attract more Muslim tourists.

Among the travel characters assessed in this study: Status, influencer, information search, and considering to choose destination, only on the information search level variable shows that Indonesian consumers has a significant difference in motivation. By information searches through print media, Indonesian consumers will be more motivated to visit Malaysia, but its does not apply for Malaysian consumers. The level of respondent Indonesia motivation differs significantly among different levels of environment factors, such as Muslim norm, social class, family, religion condition and friends. While for Malaysian consumers, the same applies, except friends. Friends in this sense means as a reference group that make effect to get the motivation to purchase or not.

Furthermore, the motivation has positive influence to Indonesian and Malaysian Muslim tourist on attitude in trips both to Indonesia and to Malaysia. Altering consumer attitude is a key for marketing strategy. Marketers have to create positive attitudes in consu mer minds in order to attract them in comparison with the competitors' services.

This study contained several limitations. First, this study examined Muslim travelers' motivation in Indonesia and Malaysia. Their travel motivations and attitudes can differ from other non-Islamic countries. As an extension of this study, future research should test the effectiveness of our proposed conceptual framework in other non-islamic destinations. Second, this research focused on the influence of demographics, travel characteristics, and environmental factors on the motivation of Muslim tourists and their relationship to attitude. It is recommended to conduct further research by using other determinants of motivation to confirm their effects.

\section{REFERENCES}

Abror, A., Wardi, Y., Trinanda, O., \& Patrisia, D. (2019). The impact of Halal tourism, customer engagement on satisfaction: moderating effect of religiosity. Asia Pacific Journal of Tourism Research, 24(7), 633-643.

Agyeiwaah, E., Felix, E.O., Wantanee, S. \& Wei-Jue, H. (2019). Understanding culinary tourist motivation, experience, satisfaction, and loyalty using a structural approach. Journal of Travel \& Tourism Marketing, 36(3), 295-313.

Ajzen, I. \& Fishbein, M. (2000). Attitudes and the attitude-behavior relation: Reasoned and automatic processes. European Review of Social Psychology, $11(1), 1-33$.

Alén, E., Losada, N., \& Domínguez, T. (2016). The impact of ageing on the tourism industry: An approach to the senior tourist profile. Social Indicators Research, 127(1), 303-322. https://doi.org/10.1007/s11205-015-0966-x.

Arizon, M.J.B., Andres, E.F., \& Vallejo, E.M. (2010). Identification of the profiles of women who take holiday decisions. Tourism Review, 65(1), 4-17. DOI $10.1108 / 16605371011040870$.

Auf, M.A.A., Meddour, H., Saoula, O., \& Majid, A.H.A. (2018). Consumer buying behaviour: the roles of price, motivation, perceived culture importance, and religious orientation. Journal of Business and Retail Management Research, 12(4), 177-186.

Baker J.P \& Ritsuko O. (2008). Pro-enviromental products: Marketing influence on onsumer purchase decision. Journal of Consumer Marketing, 25 (5), 281-293. 
Battour, M., Ismail, MN, \& Battor, M. (2017). Islamic tourism: an empirical examination of travel motivation and satisfaction in Malaysia. Current Issues in Tourism, 20(1), 50-67.

Beerli, A., \& Martín, J.D. (2004). Tourists' characteristics and the perceived image of tourist destinations: A quantitative analysis-A case study of Lanzarote, Spain. Tourism Management, 25(5), 623-636.

Boo, S., \& Jones, D.L. (2009). Using a validation process to develop market segmentation based on travel motivation for major metropolitan areas. Journal of Travel \& Tourism Marketing, 26(1), 60-79.

Caber, M., \& Albayrak, T. (2016). Push or pull: Identifying rock climbing tourists' motivations. Tourism Management, 55, 74-84.

Chek, Y.L. (2014). Image of Taiwan held by Malaysian Muslim tourist: Motivational factors influencing overall image evaluations. Malaysian Management Journal, 18 (18), 75-91.

Chu, S-C. (2011). Viral advertising in social media: Participation in Facebook groups and responses among college-aged users. Journal of Interactive Advertising, 12(1), 30-43. DOI: 10.1080/15252019.2011. 10722189

Cosmin, D.A. (2012). Factors that influence consumer purchasing decision of organic food. Thesis, Alexandru Ioan Cuza University of Iasi, Rumania (RO).

Decrop, A. (2005). Group Processes in Vacation Decision-Making. Journal of Travel \& Tourism Marketing, 18(3), $23-36$.

El-Gohary, H. (2016). Halal tourism, is it really halal? Tourism Management Perspective, 19(B), 124-130.

Engel, J.F., Blackwell, R.D., \& Miniard, P.W. (1995). Consumer behavior, Dryden Press.

Fu, X., Juhee K. \& Asli T. (2017). Self-congruity and flow as antecedents of attitude and loyalty towards a theme park brand. Journal of Travel \& Tourism Marketing, 34(9), 1261-1273

Fodness, D., \& Murray, B. (1999). A model of tourist information search behavior. Journal of Travel Research, 37(3), 220-230.

Global Muslim Travel Index 2019. (2019). Mastercard-CrescentRating: Global Muslim Travel Index 2019. available at https://www.crescentrating.com/reports/global-muslim-travel-index2019.html (accessed 16 October 2019).

Grimm, B., Lohmann, M., Heinsohn, K., Richter, C., \& Metzler, D. (2009). The impact of demographic change on tourism and conclusions for tourism policy. Federal Ministry of Economics and Technology, Germany, July 2009.

Hamed, H.M. \& Elmoghazy, M.A. (2018). The influence of place of residence on the Muslim tourist's destination choice when favoring between Muslimfriendly destinations and other tourist destinations. European Journal of Hospitality and Tourism Research, 6(1), 1-28.

Han, H., Amr, A., Mehmet, A.K., Pearl M.C.L, Jinah, P., Jongsik, Y., \& Wansoo, K. (2019). Halal tourism: Travel motivators and customer retention. Journal of Travel \& Tourism Marketing, 36(9), 1012-1024.

Hassan, Z. (2015). Factors affecting Muslim tourist choice of halal concept hotels and satisfaction in Malaysia: Moderating effect of religious devotedness. International Journal of Accounting \& Business Management, 3(2), 133-143.

Hawkins, D \& Mothersbaugh, D. (2010). Consumer Behaviour. Building Marketing Strategy. Eleventh Edition, McGraw Hill Irwin, New York City (US).

Jaelani, A. (2017). Halal tourism industry in Indonesia: potential and prospect. International Review of Management and Marketing, 7(3), 25-34.

Jang, S.C., \& Cai, L.A. (2002). Travel motivations and destination choice: A study of British outbound market. Journal of Travel \& Tourism Marketing, 13(3), 111-133.

Jeaheng, Y., Al-Ansi, A., \& Han, H. (2019). Halal-friendly hotels: Impact of halal-friendly attributes on guest purchase behaviors in the Thailand hotel industry. Journal of Travel \& Tourism Marketing, 36(6), 730-747.

Jensen, J. \& Hjalager, A. M. (2013). The role of demographics and travel motivation in travellers' use of the internet before, during, and after a trip. International Journal of Tourism Policy, 5(1/2), 34-58.

Jiang, S., Scott, N. \& Ding, P. (2015). Using means-end chain theory to explore travel motivation: An examination of Chinese Outbound tourists. Journal of Vacation Marketing, 12(1), 87-100.

Jones, V.R. (2011). Motivations to cruise: An itinerary and cruise experience study. Journal of Hospitality and Tourism Management, 18 (1), $30-40$.

Jonsson, C. \& Dwayne, D. (2008). Does nationality, gender, and age affect travel motivation? a Case of Visitors to the Caribbean island of Barbados. Journal of Travel \& Tourism Marketing, 25(3-4), 398-408.

Kattiyapornpong \& Miller. (2008). Socio-demographic constrains to travel behavior. International Journal of Culture, Tourism and Hospitality Research, $3(1), 81-94$.

Kellerman, A. (2014). The satisfaction of human needs in physical and virtual spaces. The Profesional Gheographer, 66(4), 538-546. DOI: $10.1080 / 00330124.2013 .848760$.

Kementrian, P. (2015). Kajian Pengembangan Wisata Syariah. available at http://www.kemenpar.go.id/userfiles/2015\%20Kajian\%20Pengembangan\% 20Wisata\%20Syariah.pdf (accessed 7 Februari 2018).

Kementrian, P., \& Kebudayaan, M. (2017). Profil Pencapaian dan Pengiktirafan. available at http://www.motac. gov.my/ profil/pencapaian-dan-pengiktirafan (accessed 22 Januari 2017).

Kettani, H. (2010). World Muslim Population: 1950 - 2020. International Journal of Environmental Science and Development, 1(2), 1-42.

Kim, H., Seungwoo L., Muzaffer U., Juyeon K. \& Kyungmo A. (2015). Nature-based tourism: Motivation and Subjective well-being. Journal of Travel \& Tourism Marketing, 32(sup 1), S76-S96.

Kim, M., \& Chulwoo, K. (2020). Lifestyle and travel motivation of the elderly in South Korea: baseline characteristics and the relationship between demographic factors. International Journal of Hospitality \& Tourism Administration, 21(2), 141-164.

Kim, C. \& Seokho, L. (2000). Understanding the Cultural Differences in Tourist Motivation between Anglo-American and Japanese Tourists. Journal of Travel \& Tourism Marketing, 9(1-2), 153-170.

Kim, S.S., Yim, K.P.W., \& Steve P. (2015). Differences in tourist attitude and behavior between maindland Chiness and Taiwane se tourist. Journal of Travel \& Tourism Marketing, 32, 100-115.

Khan, F., \& Michelle, C. (2017). The halalification of tourism. Journal of Islamic Marketing, 8(4), 558-577.

Khalabikhina, I.E., \& Shishalov, D. (2016). Socio-demographic portrait of Russian travelers. Worldwide Hospitality and Tourism Themes, 8(3), 287 - 295.

Kozzak, M. (2002). Comparative analysis of tourist motivations by nationality and destinations. Tourism Management, 23(3), 221-232.

Kwun, D.J.W. (2011). Effects of campus foodservice attributes on perceived value, satisfaction, and consumer attitude: A gender-difference approach. International Journal of Hospitality Management, 30(2), 252-261.

Laderlah, S., Rahman, A.S., Awang, K., \& Man, Y. (2011). A Study on Islamic tourism: A Malaysian experience. 2nd International Conference on Humanities, Historical and Social Sciences IPEDR vol. 17, IACSIT Press, Singapore.

Lee, S. \& Gyumin, L. (2014). Ecotourists' motivation and revisit intention: A case study of restored ecological parks in South Korea. Asia Pacific Journal of Tourism Research, 19(11), 1327-1344.

Lee, J. \& Hwang, J. (2011). Luxury marketing: The influences of psychological and demographic characteristics on attitudes toward luxury restaurants. International Journal of Hospitality Management, 30(1), 658-669.

Li, M. \& Cai, L. A. (2016). The effects of personal values on travel motivation and behavioral intention. Journal of Travel Research, $20(10), 1-15$.

Lou, J. (2014). Analysis of adventure tourist motivation: The case of China-born international students in New Zealand universities. Master dissertation, Auckland Univerity of Technology, New Zealand.

Ma, A.T.H., Chow, A.S.Y. Cheung, L.T.O., Lee, K.M.Y., \& Liu, S. (2018). Impacts of tourists' sociodemographic characteristics on the travel motivation and satisfaction: The case of protected areas in South China. Sustainability, 10(3388), 1-21.

Maghrifani, D. (2018). Emerging sharia hotel in Indonesia: Understanding the tourists' motivation and values. International Journal of Business and Society, 19(4), 661-675.

Mahmoud, A.B. (2014). Linking information motivation to attitudes towards web advertising. Journal of Islamic Marketing, 5(3), 396-413.

Mak, A.H.N., Lumbers, M., Eves, A., \& Chang, R.C.Y. (2012). Factors influencing tourist food consumption. International Journal of Hospitality Management, 31 (3), 928-936. 
Muhammad, K.R. (2017). What travel motivational factors influence Muslim tourists towards MMITD? Journal of Islamic Marketing, 8(1), 48-73.

Najib, M. \& Kiminami, A. (2011). Competitive strategy and business performance of small and medium enterprises in the Indonesian food processing industry. Studies in Regional Science, 41(2), 315-330.

Nengovhela, M., Ndivhuwo, T., \& Siyabulela, N. (2017). Domestic tourism in practice: an investigation of Vhembe District Municipality residents' travel motivations. African Journal of Hospitality, Tourism and Leisure, 6(4), 1-15.

Nurlaela, S., Sumarwan, U., \& Najib, M. (2019). Determinants of online journey and its influence on online customer satisfaction associated with online customer loyalty', Int. J. Electronic Marketing and Retailing, 10(3), 230-243.

Otoo, F.E., Kim, S., \& Choi, Y. (2020). Understanding senior tourists' preferences and characteristics based on their overseas travel motivation clusters. Journal of Travel \& Tourism Marketing, 37(2), 246-257.

Perrett, C. (2007). Travel motivation of Independent youth leisure travelers. Master thesis, The University of Manitoba, Winnipeg, Canada (US).

Pramika D. (2017). Faktor-Faktor Yang Mempengaruhi Pendapatan Rumah Tangga. Jurnal Ekonomi, Manajemen, Bisnis, Auditing, dan Akuntansi, 2 (1), 33-49.

Qi, S., Law, R., \& Buhalis, D. (2013). Who booked five-star hotels in Macau? A study of hotel guests' online booking intention. Journal of Hospitality \& Tourism Management, 20, 76-83.

Ryu, E., Hyun, S.S., \& Shim, C. (2015). Creating New Relationships Through Tourism: A Qualitative Analysis of Tourist Motivations of Older Individuals in Japan. Journal of Travel \& Tourism Marketing, 32(4), 325-338.

Suid, I.S., Nor, N.A.M., \& Omar, H. (2017). A review on Islamic tourism and the practical of Islamic attributes of destination in tourism business. International Journal of Academic Research in Business and Social Sciences, 7(12), 255-269.

Suradin, M. (2018). Halal tourism promotion in Indonesia: An analysis on official destination websites. Journal of Indonesian Tourism and Development Studies, 6(3), 143-158.

Tan, A.Y.F., McCahon, C., \& Miller, J. (2002). Modelling tourist flows to Indonesia and Malaysia. Journal of Travel and Tourism Marketing, $13,61-82$.

Taylor, D.G., Lewin, J.E., \& Strutton, D. (2011). Friends, Fans, and Followers: Do Ads Work on Social Networks? How Gender and Age Shape Receptivity. Journal of Advertising Research, 51(1), 258-275.

Vainikka, B. (2015). Psychological factors influencing consumer behavior. Bachelor thesis, Centria University of Applied Science, Finland.

VanVoorhis, C.R.W., \& Morgan, B.L (2007). Understanding Power and Rules of Thumb for Determining Sample Sizes. Tutorials in Quantitative Methods for Psychology, 3 (2), 43-50.

Yeong, K., Eves, A. and Scarles, A. (2009). Building a model of local food consumption on trips and holidays: A grounded theory approach. International Journal of Hospitality Management, 28, 423-431.

Zhang Y, Peng Y. (2014). Understanding travel motivation of Chinese tourists visiting cairns Australia. Journal of Hospitality and Tourism Management. 21, 2144-2153.

*** Departement of Culture and Tourism, (2017). World Halal Tourism Summit. available at http://tcaabudhabi.ae/en/events/our.events/halal.tourism.aspx. (accessed 9 Februari 2018).

Accepted: 26.06.2020

Available online: 13.07.2020 